\title{
Quality of Goods, Demand and Utility
}

\author{
Ismagilova Gulnara N. ${ }^{1}$, Medvedeva Yulia ${ }^{2}$, Safiullin Marat R. ${ }^{1}$, Safiullin Lenar N. ${ }^{1}$ \\ ${ }^{1}$ Kazan Federal University, Kazan, Russian Federation \\ ${ }^{2}$ National Research Nuclear University MEPhI, Moscow Engineering Physics Institute, Kashirskoye shosse 31, \\ Moscow, Russian Federation \\ Correspondence: Ismagilova Gulnara N., Kazan Federal University, Kazan, 420008, Russian Federation. E-mail: \\ lenar_s@mail.ru; 13yulia78@mail.ru
}

Received: August 21, 2014 Accepted: September 4, 2014 Online Published: November 27, 2014

doi:10.5539/ass.v10n24p159 URL: http://dx.doi.org/10.5539/ass.v10n24p159

\begin{abstract}
This paper are investigated questions of interrelation of quality and demand and are considered concepts, which limiting utility, quality and demand On the basis of revealing of interconnection between theories of welfare and markets of imperfect competition, by quality non-homogeneity of goods and services, consumers and producers there determines the influence of public welfare on mechanisms of imperfect competition market and their adverse effect on public welfare which includes stimulation of demand and growth of welfare on the basis of rising level of quality of produced and consumed goods and services. In this article we tried to complete and expand the scientific results in the field of theory quality, value and profits by identifying mechanisms of influence the quality of goods and services to offer the producer, the consumer utility and the utility of the formation of their benefits (profit and utility).
\end{abstract}

Keywords: consumer, demand, quality, marginal utility on quantity, quality management

\section{Introduction}

Stages of the economic development and its features have been already occurred in the present developed countries. They have obtained such names as "post-industrial economy" information economy "and" the economy based on knowledge." A characteristic feature is the presence of the information components of knowledge in products and services. In other words, the basis of economic benefit of both consumers and producers is the using of specialized knowledge and that they have the relevant information (Marshall, 1983).

In these circumstances one need more generalized and adequate to current realities models of consumer behavior and demand-which include the competition, incomplete information and studying. Consumers weakly differentiate brands and manufacturers of new products for them. Firstly they accidentally choose a product, chaotically, only then in the process of consumption they assess the quality. Competitors fill the market at the same time with the similar, low-quality products. Customers lose the confidence in the quality of all these products-the demand and the price drop and as the result we get the market degradation. In such cases neither consumer protection measures nor legislation can help if not to explore and make sense of this phenomenon in relation to many factors of demand and market signals. One need new models of the market demand in relation to the quality, conditions of uncertainty and unknown quality of the goods.

In this article we would like to answer some of these questions.

\section{Data and Methodology}

The concept of demand means a necessity, want or desire to have any goods, supported by the amount of money which is needed to purchase it. In economics, the demand is always based on the willingness and ability to pay, not only on the necessity of goods. The total demand of consumers' goods is described by the functional connection of the factors or can be reflected in the demand curve (Anderson, 1993).

But we should not think that the power of money eliminates the stimulation of demand by other factors.

Approach which includes the using of graphics in the study of the demand has been proposed and widely used by the British economist A. Marshall in his work "The principles of Economics ", published in 1890. He wanted to determine at what price to the particular commodity the market equilibrium would be established. This fact caused him to think that the commodity price was the function $\mathrm{p}$, and the argument-the number of the product 
demand Qp.

This initial phase of the economic categories of demand study was, in fact, a factor demand, i.e. it derived the dependence of demand on the one factor-on the price at a constancy of other factors. It should be noted that, historically, the competition in the market economy started with the dominance of the methods of price competition. This situation was typical for the period of free competition. It was caused by a well- known constancy of the needs system and of the range and quality of goods. Therefore, A. Marshall studied only the dependence of the volume of demand on the one factor-on the price. He studied the factor demand from the price at the constancy of other factors.

However the demand-is a broader concept which depends on many factors that influence consumer demand. From the position of joint consideration of demand and competition and in order to determine the consumer benefits we offer to enter another important factor-the quality of the goods into many other known demand factors. Since the Marshall research to the present time features of the goods, exactly, the quality of the product was undergoing great changes. Quality has become more important than price. As a result, new methods of competition have been occurred, including non-price competition, focused mainly on the quality of the goods.

The law of demand establishing a link between the quantity (volume) of the demand and the price of the goods was derived in the empirical way. However, in our opinion, in competitive markets, consumers are interested not only in the price of the goods, but in the quality and competitiveness which shows the level of their well-being.

\section{Results (Obligatory)}

In the process of purchasing the product consumer (consumers) as if "weighs" the quality of the product with its price. In economic theory, as a rule, we study the effective demand, which characterizes not only desire, but also the opportunity to buy the commodity. Due to the competition low-quality goods leave the markets, because of poor quality they are not able to compete, consumers don't want to make worse their welfare buying such items (Deming, 1982).

Suppose that there is market balance on the market, it characterized by balanced price p11 of goods with quality $\mathrm{g} 1$ and balanced volume Q11(g1), and costs of its production C1(Q11, g1, p11).

With the increase of quality up to the level g2producer will surely will have additional expenses for obtaining and providing of higher quality, which will stipulate for larger costs $\mathrm{C} 2(\mathrm{Q} 11, \mathrm{~g} 2, \mathrm{p} 11)$. In this connection according to the law of supply, producer's wish to produce goods and offer it to the market will go down, because the norm of profit with permanent price for producer will reduce to $\Delta \mathrm{C}=\mathrm{C} 2(\mathrm{Q} 11, \mathrm{~g} 2, \mathrm{p} 11)-\mathrm{C} 1(\mathrm{Q} 11, \mathrm{~g} 1$, p11). As a result it will lead to displacement of supply curve $S 1$ (g1) to the left to the position B S2(g2) (Figure 1).

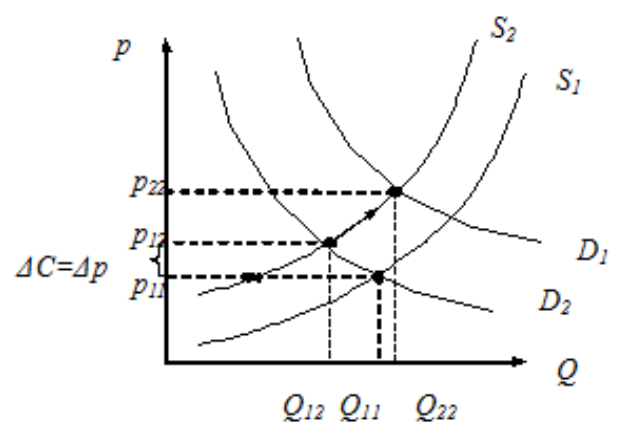

Figure 1. Model of influence of quality on demand and supply

According to supposed law of demand from quality, with increase of quality the volume of goods consumption must increase, which will provide displacement of demand curve $\mathrm{D} 1$ (g1)to the positionD2(g2), i.e. to the right. Thus there will be new balanced price on the market $\mathrm{p} 22$.with balanced volume Q22.Thus there can appear three occasions, when Q22 > Q11, Q22 = Q11, Q22 < Q11, but there must be held a condition of increase of original profit $\Pi(\mathrm{g} 1)$ over profit at the qualityg2- $\Pi(\mathrm{g} 2)$, i.e. $\Pi(\mathrm{g} 2)>\Pi(\mathrm{g} 1)$, in other words condition of appearance a new norm of producer's profit, larger than with the quality and g1).

Considering this question we proceed from Smith's self-interest when everyone maximizes either utility in case of consumer, or profit in case of producer i.e. we consider not a social man who cares about social well-being and increases quality without getting additional profit but a producer who takes economic decisions for his own 
welfare.

In such reasoning there is some ambiguity about increase of consumption of better quality production. You know the expression-"We are not that rich to buy cheap things". In this case "cheap things" means low quality things (goods). It's well-known that it's better to buy one quality thing even if it is more expensive, than purchase low quality things at a lower price. (Figure 2). For example to buy good and expensive iron "Tefal" for longer working period than to buy cheaper iron with less functions every year.

Thus we can suppose that the volume of quality goods consumption may not increase, but even decrease, which means displacement of the curve of demand D1(g1)not to the left but will go either up, which will correspond with former level of balanced volume of consumption Q11(g2) = Q11(g1), or also will go up with the lowering of consumption volume, in any case the price of goods will increase.

In the process of such reasoning there appears necessity to explain in what conditions takes place the movement of the curve of demand to the right or up with the decrease of balanced volume. At our point of view we can suppose that given variants are stipulated by the degree of increase of production quality, which is graphically characterized by the degree of curve displacement to the left.

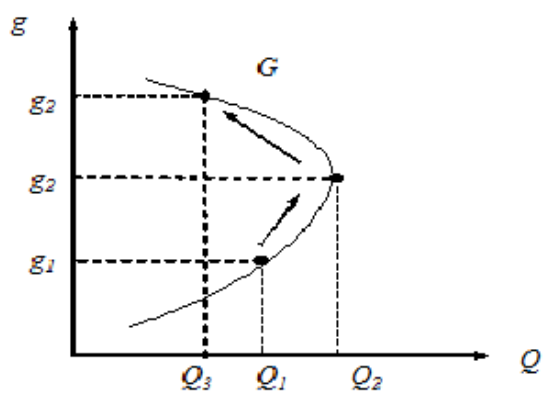

Figure 2. Curve of demand from quality

Insignificant change of quality side of production is caused as a rule by insignificant increase of additional expenses (if we are not talking about improvement of expensive and high-tech production brought to the high degree of perfection.) Therefore, the norm of profit with insignificant increase of expenses will change also insignificantly and we can (according to producer's behavior) state that curve of supply will displace to the right by insignificant value. At that demand, to be precise the volume of consumption will increase or stay on the former level Q11(g2) (which can be characteristic also for the second case). AS a result the price of production will increase by the larger value than growth of additional costs $\Delta \mathrm{C}$ and therefore the norm of producer's profit will increase.

In the third case, when the curve of demand displaces up with the decrease of consumption volume there will be significant change in quality level. As a result the displacement of the curve of supply to the left will be significantly bigger than in the first and second cases. At that we can state that utility of each item of such production will by many times exceed production with lower quality. Since value of quality goods for consumer is significantly higher. Therefore general utility is reached by less quantity of goods. That's why quantity of consumption of high-quality goods is lower. (Figure3).

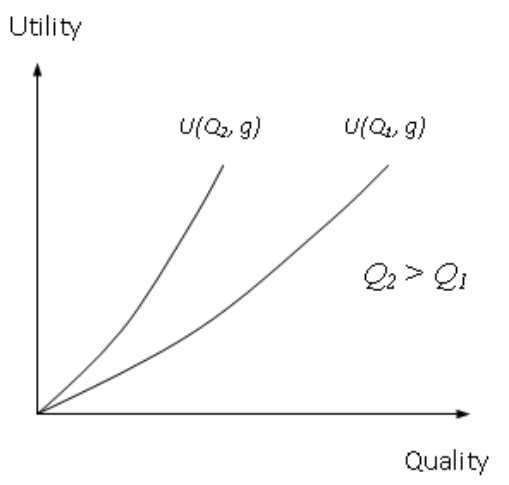

Figure 3. Behavior of utility from quality at the different levels of consumption 
Understanding of demand, supply and utility interaction mechanisms, methodological work out of questions of influence of quality on market forms of management will enable to do production activity of management subjects of all levels more effectively.

In well-known works of marginalists utility is considered as function or dependence from volume of consumption. At that quality is not taken into account. Obviously the researches of marginalists can be considered as some simplification i.e. with invariability of goods quality. Even if they wanted to take quality into consideration they couldn't do it because quality as a value wasn't estimated.

We can consider well-known results ofmarginalists' theory of utility as some particular case, i.e. consider utility like function of two variables-quantity and quality, but with fixed invariable quality, i.e. $U=U(g, Q), g=$ const.

Such approach was used by A. Marshall while developing the theory of demand and supply. He considered demand and supply as a function from price with other things being equal. So there was introduced the principle "Other things being equal." However non-price factors in his works were considered as factors influencing on the shift of demand or supply lines.

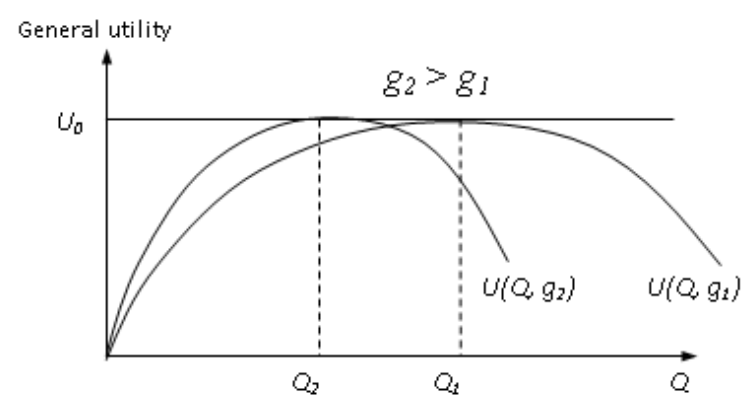

Figure 4. Graphs of general utility for two levels of quality

Let's formulate the following axioms: quality and quantity of goods are arguments of the function of utility (this is hypothesis of the research axiom 1)

2 axiom the higher is quality the higher is utility i.e. $\mathrm{U}(\mathrm{g} 2)>\mathrm{U}(\mathrm{g} 1)$ приg2 $>\mathrm{g} 1$.

However in the works of marginalists we don't meet the shift of the curve of utility. Let the utility be $U=U(g$, $\mathrm{Q}), \mathrm{g}=$ const. Then utility in dependence of $\mathrm{Q}$ behaves as follows:

Family of graphs of utility for different quality g2> g1 presented on Figure

Given utility at increase of quality of goods is reached at less volume.

Law and the same utility at increase of quality of the same type product is reached at less volume of its consumption.

For example fresh apples contain more vitamins than apples, stored for a long time. That's why for replenishment of organism by needed vitamins one need to eat less volume of fresh apples compared to long-stored apples.

\section{Conclusions}

In this article we tried to complete and expand the scientific results in the field of theory quality, value and profits by identifying mechanisms of influence the quality of goods and services to offer the producer, the consumer utility and the utility of the formation of their benefits (profit and utility).

In economic theory, the total gain is interpreted as a social welfare and is denoted as W $=$ CS + PS, where CS-profit (surplus) of consumers, equal to the area under the curve bounded at the top of the demand curve, the bottom line of the market price,

PS-profit (surplus) of manufacturers of equal area bounded at the top line of the market price, the bottom of the supply curve.

As it was mentioned earlier the consumers benefit is the difference between the maximum amount of money that consumers are ready to pay for a given quantity of the goods and their actual costs, based on the current market prices for these goods. For the consumers it is the area between the demand curve and the market price line. 
In work there was obtained the following dependence: producers-sellers increase volume of supply of goods with the rise of price, lowering of quality and competition, which connected with decrease of expenses for providing the given low quality level and competitiveness of goods. The largest volume of supply is reached with maximal price minimal possible quality level and competitiveness requests of goods. And vice versa the least volume of supply is reached with minimal price and high quality of goods and competitiveness requests. At the same time the volume of supply increases with the growth of demand level on high-quality goods.

Limit quality welfare can be defined as an additional increment of social welfare by increasing the level of quality of goods consumed by one additional unit. Changes in the level of quality also imply some change in the consumption.

The growth of social welfare as a result of improving the quality is provided by the increment of consumer surplus and the profit (surplus) of the manufacturer (shaded area).

In our opinion, the qualitative growth of wealth-this is a trend to increase the amount of consumer high-quality surplus and manufacture high-quality surplus which is derived from improving the quality of goods and services.

Qualitative growth of social welfare is a function of the growth of high-quality consumer and manufacture surplus when the level of quality of consumer goods and services changes.

In work there was obtained the following dependence: producers-sellers increase volume of supply of goods with the rise of price, lowering of quality and competition, which connected with decrease of expenses for providing the given low quality level and competitiveness of goods. The largest volume of supply is reached with maximal price minimal possible quality level and competitiveness requests of goods. And vice versa the least volume of supply is reached with minimal price and high quality of goods and competitiveness requests. At the same time the volume of supply increases with the growth of demand level on high-quality goods.

Limit quality welfare can be defined as an additional increment of social welfare by increasing the level of quality of goods consumed by one additional unit. Changes in the level of quality also imply some change in the consumption.

Economical sense of these two conditions consists in following: the first condition is connected with the growth of consumers demand as a result of rise of goods quality, which happens as a result of qualitative stimulation of consumes demand. The second condition is connected with producer's gain of additional profit as a result of sales of quality goods by higher price than goods of lower quality level, which also, eventually, is the result of qualitative stimulation of producer's supply.

\section{References}

Aghion, P., \& Tirole, J. (1977). Formal and real authority in organizations. Journal of Political Economy, 105(1), 1-29. http://dx.doi.org/10.1086/262063

Anderson, E. W., Fornell, C., Lehmann, D. R., \& Sullivan, M. W. (1993). The antecedents and consequences of customer satisfaction for firms. Marketing Science, 12(2), 125-143. http://dx.doi.org/10.1287/mksc.12.2. 125

Béraud, A. (2013, April). French economists and the purchasing power of money. European Journal of the History of Economic Thought, 20, 349-371. http://dx.doi.org/10.1080/09672567.2012.708771

Berg, N. (2014). Success from satisficing and imitation: Entrepreneurs' location choice and implications of heuristics for local economic development. Journal of Business Research, 67(8), 1700-1709. http://dx.doi. org/10.1016/j.jbusres.2014.02.016

Bolton, R. N., \& Lemon, K. N. (1999). A dynamic model of customers' usage of services: Usage as an antecedent and consequence of satisfaction. Journal of Marketing Research, 36(2), 171-186. http://dx.doi. org $/ 10.2307 / 3152091$

Brown, M. G., \& Lee, J. Y. (2010). Preference variable impacts in direct and inverse differential demand systems. American Journal of Agricultural Economics, 92(3), 889-898. http://dx.doi.org/10.1093/ajae/aap036

Cadotte, E. R., Woodruff, R. B., \& Jenkins, R. L. (1987). Expectations and norms in models of consumer satisfaction. Journal of Marketing Research, 24, 305-314. http://dx.doi.org/10.2307/3151641

Deming, W. E. (1982). Quality, Productivity, and Competitive Position. Cambridge, MA: MIT Press.

Espinoza, R., \& Tsomocos, D. (2014). Monetary transaction costs and the term premium. Economic Theory, 4. http://dx.doi.org/10.1007/s00199-014-0817-z 
Grandgirard, A., \& Kalivas, T. (2009). Mapping community values for natural capital and ecosystem services. Ecological Economics, 68(5), 1301-1315. http://dx.doi.org/10.1016/j.ecolecon.2008.12.006

Kalenskaya, N. V., \& Novenkova, A. Z. (2012). The regional development strategy based on territorial marketing (the case of Russia). World Applied Sciences Journal, 18(Special Issue of Economics), 179-184.

Kamasheva, A., Kolesnikova, J., Karasik, E., \& Salyakhov, E. (2013). Discrimination and Inequality in the Labor Market. Procedia Economic and finance, 5, 386-392. http://dx.doi.org/10.1016/S2212-5671(13)00046-4

Larionova, N. I., \& Varlamova, Y. A. (2013). The Trends of Household Economic Behavior in International Comparison. Procedia Economic and finance, 5, 737-746. http://dx.doi.org/10.1016/S2212-5671 (13)00086-5

Malyshkov, V. I. (2013). Some aspects of the effective relations between government and business. Life Science Journal, 10(4), 2679-2682.

Marshall, A. (1983). Principles of Economics (6th ed.).

Novenkova, A. Z., Kalenskaya, N. V., \& Gafurov, I. R. (2013). Marketing of Educational Services: Research on Service Providers Satisfaction. Procedia Economic and finance, 5, 667-676.

Panasyuk, M. V., Pudovik, E. M., \& Sabirova, M. E. (2013). Optimization of regional passenger bus traffic network. Procedia Economic and finance, 5, 589-596. http://dx.doi.org/10.1016/S2212-5671(13)00069-5

Papanikolaou, D. (2011). Investment shocks and asset prices. Journal of Political Economy, 119(4), 639-685. http://dx.doi.org/10.1086/662221

Schley, D. R., \& Peters, E. (2014). Assessing "Economic Value": Symbolic-Number Mappings Predict Risky and Riskless Valuations. Psychological Science, 25(3), 753-761. http://dx.doi.org/10.1177/0956797613515485

Zhi, H. (1995). Risk management for overseas construction projects. International Journal of Project Management, 13(4), 231-237. http://dx.doi.org/10.1016/0263-7863(95)00015-I

\section{Copyrights}

Copyright for this article is retained by the author(s), with first publication rights granted to the journal.

This is an open-access article distributed under the terms and conditions of the Creative Commons Attribution license (http://creativecommons.org/licenses/by/3.0/). 